\title{
Library Resources and Services of Selected Deemed University Libraries in Andhra Pradesh, India
}

\author{
K.Ramakrishna \\ Research Scholar, Javaharlal Nehru Technological University, Kakinada (JNTUK) \\ Andhra Pradesh
}

\begin{abstract}
This paper defines the role of selected Deemed University libraries in Andhra Pradesh, Indian in higher education and research of Engineering, Science and technology. This paper systematically studies the operational, the resources and services of these libraries. The collection development, library membership, staff position, working hours, library automation, services offered and availability of online resources are also discussed.

Keywords: Deemed University libraries, Academic libraries, Library resources and services, Library automation, Andhra Pradesh
\end{abstract}

\section{INTRODUCTIION}

Deemed University libraries play a vital role in the achievement of the Institution .It is an integral part of the teaching learning process at the academic level. In order to successfully play its role in the university system a library must have appropriate resources like information resources, staff, space, etc. The University libraries make effort to better serve the users by providing maximum service with their available means or resources. In the light of this, the library can serve its users effectively only when it knows their specific requirements. The Kothari commission in its report on education and national development (1964-66) further emphasised that ' No university, college or department should be set up without taking into account its library needs in terms of staff, journals, space, etc. Nothing could be more damaging to a growing department than to neglect its library, the library should be an important centre of attraction on the college or university campus.

The study is an attempt to present a comprehensive and up to date overview of library services and their resources in the state of Andhra Pradesh, India. The present study covers three selected Deemed Universities.

\section{Description of Universities}

GITAM Institute of Technology and Management (GITAM) ( a deemed to be university u/s 3 of the UGC Act, 1956) known as GITAM University is an educational institution in India. It was previously known as GITAM College, affiliated to Andhra University. Established in 1980, it was conferred the status of deemed university in 2007. It was the first private engineering institute in Andhra Pradesh to receive university status. The University has three picturesque campuses, it is main campus Visakhapatnam spreads over 100 acres, and the other two campuses are at Hyderabad and Bangalore. The University offers 109 programs at undergraduate, post graduate and Doctoral levels in Technology, Pharmacy, Science, Management, International Business, Architecture and Law with an intake of approximately 10000 students $^{\mathbf{6}}$.

K L University, Officially the Koneru Laksmaiah Educational Foundation, is a deemed university located in the Vaddeswaram Guntur District of Andhra Pradesh, India. K L University consists of 11 academic departments and six schools, with a strong emphasis on scientific and technological research. Approximately 10000 students Established in 1980, the college became Autonomous in the year 2006 and from 2009 onwards it has become Deemed to be University located at on a $100 \mathrm{acres}^{7}$.

Vignan University (VU) is located in the Guntur district, Andhra Pradesh. The institution was established as Vignan Engineering College in 1997 and was affiliated to Jawaharlal Nehru Technological University, Hyderabad as a part of the Vignan Foundation for science, Education \& Research. It was conferred the status of a Deemed University by the University Grant Commission, Government of India in 2008 and was renamed Vignan University. It is funded by Vignan Group 11 academic and 7000 students ${ }^{\mathbf{8}}$.

Table 1. Description of Universities

\begin{tabular}{|c|c|c|c|c|c|}
\hline Name of the university & Approval & Website Address & $\begin{array}{l}\text { Year of } \\
\text { Established } \\
\text { institution }\end{array}$ & $\begin{array}{l}\text { Year of to } \\
\text { deemed } \\
\text { university }\end{array}$ & Abbreviations \\
\hline $\begin{array}{lr}\text { GITAM } & \text { University, } \\
\text { Visakhapatnam, } & \text { Andhra } \\
\text { Pradesh } & \\
\end{array}$ & UGC, AICTE,NAAC & www.gitam.edu & 1980 & 2007 & GITAM \\
\hline $\begin{array}{l}\mathrm{K} \\
\text { Vaddeswaram , Guntur District } \\
\text { of Andhra Pradesh, India }\end{array}$ & $\begin{array}{l}\text { UGC, AICTE,NAAC, } \\
\text { ISO 9001:2008 }\end{array}$ & www.kluniversity.in & 1980 & 2009 & KLU \\
\hline $\begin{array}{l}\text { Vignan University, Guntur } \\
\text { district, Andhra Pradesh }\end{array}$ & $\begin{array}{l}\text { UGC, AICTE,NAAC } \\
\text { \&NBA, ISO 9001:2000 }\end{array}$ & $\begin{array}{l}\text { www.vignanuniversit } \\
\text { y.org }\end{array}$ & 1997 & 2008 & VU \\
\hline
\end{tabular}




\section{Literature Review}

Seema Vasishta studied ${ }^{1}$ her paper " status of libraries in higher technical education institutions: with special reference to deemed universities of North India. Examines the present conditions in libraries in technical deemed universities north India. The study is based on the analysis of physical facilities, budget, professional staff, Organisational structure, library holdings, processing etc. Meher Singh and Ajay Kumar Arora ${ }^{2}$ discussed their paper "Library Resources and Services in the selected University libraries of Haryana, India. They studied the collection development, library membership, staff position working hours, services offered and e-resources. The survey highlighted the resources and services of the selected university libraries in Haryana and will be somewhat helpful to the society in imparting rational education to their younger generation for a better tomorrow. Daulat Jotwani $^{3}$ studied his paper "Library resources and services in Indian Institute of Technology". His paper comprehensively studies the functioning, the resources and the services of these libraries. The level of automation, availability of ICT infrastructure, access to electronic resources .It is suggested that these libraries need to move to the next level of technological up-gradation including application of cloud computing to improve their resources and services. Veena A. Prakashe and Sapana Tayade ${ }^{4}$ studied his paper" Study of E-resources of Indian Institute of Management IIM Libraries in India". The main objective is to determine the availability of different types of eresources, subscribed e-resources through consortium, memberships of library networks and collaboration with libraries. M.Madhusudahan and V.Nagabhusanam ${ }^{5}$ studied use of web-based library services in selected University libraries in India: a study. The paper highlights the current state of web-based library services against which they can benchmark their own web-based library services by university librarians in India

\section{Objectives}

-To determine the status of resources like infrastructure, collection, staff, facilities and services in the libraries of selected deemed universities

-To study the strength of both print and electronic sources of information available in the libraries

-To find the status of online resources in the university libraries

\section{Methodology}

The study was intended to know the current status of selected deemed university libraries in Andhra Pradesh. A questionnaire was prepared and personally administered to the librarians of the respective universities and responses of three selected deemed university libraries were received, which was subjected to analysis.

Table 2. Collection of Deemed University Libraries

\begin{tabular}{|l|c|c|c|}
\hline Book Collection & GITAM & KLU & VU \\
\hline Text books & $1,98,053$ & $1,17,220$ & 56695 \\
\hline e-books & $30,90,300$ & 4812 & 232 \\
\hline \multicolumn{3}{|c|}{ Journals collection } \\
\hline Indian Journals & 274 & 215 & 122 \\
\hline Foreign Journals & 51 & 95 & 2922 (online) \\
\hline Online journals & 8295 & 7833 & 2922 (online) \\
\hline \multicolumn{2}{|c|}{ Other collection } \\
\hline Educational CD's & 1560 & 7803 & 4500 \\
\hline
\end{tabular}

The Deemed University Libraries have maintaining good collection of books and journals, GITAM have 1,98,053 books , 30,90,300 e-books, 274 Indian and 51 Foreign print journals, 8295 online journals and 1560 educational cd's. KLU have 1,17,220 boos, 4812 e-books, 215 Indian and 95 Foreign print journals, 8295 online journals and 1560 educational cd's. VU have 56,695 books, 232 e-books, 122 Indian print journals, 2922 online journals and 4500 educational cd's. The also maintain a book bank containing textbooks which are loaned for a semester to the students belonging to socially and economically weaker sections of the society. 
Table 3. E-resources available in University libraries

\begin{tabular}{|l|r|r|r|}
\hline Online resources & GITAM & \multicolumn{1}{l|}{ KLU } & \multicolumn{1}{l|}{ VU } \\
\hline IEL online (IEEE-Institution of Electrical and Electronics Engineers) & $\checkmark$ & $\checkmark$ & $\checkmark$ \\
\hline ASCE(American Society of civil Engineer) & $\checkmark$ & $\checkmark$ & $\checkmark$ \\
\hline ASME(American Society of Mechanical Engineer & $\checkmark$ & $\checkmark$ & $\checkmark$ \\
\hline ASTM(American Society for Testing and Materials & $\checkmark$ & $\checkmark$ & $\checkmark$ \\
\hline Science direct & - & $\checkmark$ & - \\
\hline EBSCO & - & $\checkmark$ & $\checkmark$ \\
\hline PROQUEST & $\checkmark$ & - & - \\
\hline Springer & $\checkmark$ & $\checkmark$ & $\checkmark$ \\
\hline DELNET & $\checkmark$ & $\checkmark$ & $\checkmark$ \\
\hline Emerald & $\checkmark$ & $\checkmark$ & - \\
\hline UGC Info Net & $\checkmark$ & $\checkmark$ & $\checkmark$ \\
\hline ACM Digital Library & $\checkmark$ & - & - \\
\hline SCOPUS & $\checkmark$ & $\checkmark$ & - \\
\hline CMIE Prowess & - & $\checkmark$ & - \\
\hline Oxford University Press & - & $\checkmark$ & - \\
\hline McGrawhill Access Engineering & - & & $\checkmark$ \\
\hline NPTL Videos & $\checkmark$ & & $\checkmark$ \\
\hline ebray & $\checkmark$ & - & - \\
\hline
\end{tabular}

Here 7 electronic sources were subscribed by 3 universities, remaining electronic resources were subscribe their own requirement. GITAM University Have subscribed more electronic resources, its covers all electronic resources. Vignan University subscribed IEEE,Springer, Ebsco, ASME,ASTM,Scince direct,ASCE,Jgate, SONET Videos and NPTL Videos. The K.L University subscribed IEEE,Springer,Ebsco,ASME, ASCE,SCOPUS, McGraw hill, STM, CMIE Prowess, Knimbus Federal Search, Gale Cengage learning Architecture(GREENR),Maupatra, Lexis India, SONET Videos, NPTL Videos, MIT,Lensoo and IUCEE Videos. The Three University libraries have membership of INFLIBNET and DELNET.

Table 4. Service offered by University libraries

\begin{tabular}{|l|c|c|c|}
\hline Services & GITAM & KLU & VU \\
\hline Photo copying & $\checkmark$ & $\checkmark$ & $\checkmark$ \\
\hline CD copying & $\checkmark$ & $\checkmark$ & $\checkmark$ \\
\hline Inter library loan & $\checkmark$ & $\checkmark$ & $\checkmark$ \\
\hline Lending service & $\checkmark$ & $\checkmark$ & $\checkmark$ \\
\hline Reference service & $\checkmark$ & $\checkmark$ & $\checkmark$ \\
\hline Internet Browsing & $\checkmark$ & $\checkmark$ & $\checkmark$ \\
\hline Current Awareness service (CAS) & $\checkmark$ & $\checkmark$ & $\checkmark$ \\
\hline Selective Dissemination of Information (SDI) & $\checkmark$ & $\checkmark$ & $\checkmark$ \\
\hline User awareness Programmes & $\checkmark$ & $\checkmark$ & $\checkmark$ \\
\hline Information Literacy & $\checkmark$ & $\checkmark$ & $\checkmark$ \\
\hline News Paper clippings & $\checkmark$ & $\checkmark$ & $\checkmark$ \\
\hline Membership & $\checkmark$ & $\checkmark$ & $\checkmark$ \\
\hline OPAC/WEB-OPAC & $\checkmark$ & $\checkmark$ & $\checkmark$ \\
\hline Online lectures & $\checkmark$ & $\checkmark$ & $\checkmark$ \\
\hline Department libraries & $\checkmark$ & $\checkmark$ & $\checkmark$ \\
\hline Book bank & $\checkmark$ & $\checkmark$ & \\
\hline
\end{tabular}

The deemed University libraries provide good good library services including Current awareness service CAS, Selective dissemination Information SDI, Photo copying, CD Copying, Inter Library Loan, Lending service, Reference service, Internet browsing, OPAC, Book Bank and also provide user awareness programmes, online lecture, Information Literacy Programmes. Books Lending service is main service of the three deemed University libraries

Table 5. Working hours of the University Libraries

\begin{tabular}{|l|l|l|l|}
\hline TIME & GITAM & KLU & VU \\
\hline All working Days & $8: 00 \mathrm{am}-11 \mathrm{pm}$ & $7: 00 \mathrm{am}-11 \mathrm{pm}$ & $\begin{array}{l}\text { 7:30 am }-12.00 \mathrm{am} \\
\text { Mid night }\end{array}$ \\
\hline Sundays \& public Holidays & $9: 00 \mathrm{am}-6: 00 \mathrm{pm}$ & $10: 00 \mathrm{am}-5: 00 \mathrm{pm}$ & 10:00am $-5: 00 \mathrm{pm}$ \\
\hline
\end{tabular}

Today's every student using library facilities foe academic purpose. The opening and closing time of the deemed university libraries are shown in the table 5. GITAM University has the maximum opening time i.e., 8:00 
am to 11:00 pm, Sunday and Public holidays 9:00 am to 6:00 pm. KLU library has maximum opening time 7:00 am to 11:00 pm, Sundays and Public Holidays 10:00 am to 5:00 pm. VU library has maximum opening time 7:30 am to 12:00 am (midnight) Sundays and public holidays 10:00 am to 5:00 pm.

Table 6.Books Lending Facility for library users

\begin{tabular}{|l|l|l|l|}
\hline Library Users & GITAM & KLU & VU \\
\hline UG Students & 4 (15 days $)$ & 4 (15 days $)$ & 4 (15 days) \\
\hline PG Students \& Research Scholars & 5 (15 days) & 8 (15 days $)$ & 5 (15 days) \\
\hline Faculty & 10 (3 months) & 10 (3 months) & $10(3$ months $)$ \\
\hline Non-teaching staff & - & 4 (3 months) & - \\
\hline
\end{tabular}

Deemed University libraries provide free library membership to their students and faculty members.

Table 6. Shows the university libraries how many books lending to the users. GITAM library issuing books for lending UG students 4 books 15 days, for PG students and research scholars 5 books 15 days, for faculty members 10 books 3 months ( one semester). KLU library issuing books for UG students 4 books 15 days for PG students and research scholars 5 books 15 days, for faculty members 10 books 3 months (one semester). Only KLU library issuing 4 books 3 months for non-teaching staff. VU library issuing books for lending for UG students 4 books 15 days, for PG students and research scholars 5 books, 15 days, for faculty members 10 books 3 months.

Table 7. Staff in the University libraries

\begin{tabular}{|l|l|l|l|}
\hline Staff Position & GITAM & KLU & VU \\
\hline University Librarian & 1 & 1 & 1 \\
\hline Deputy Librarian & - & - & - \\
\hline Assistant Librarian & 6 & 5 & 3 \\
\hline Library Assistant & 11 & 16 & 5 \\
\hline
\end{tabular}

Table 7 shows staff positions of the university libraries. The deemed university libraries have recruit library professional staff for the maintaining University library. GITAM University have one University librarian, 6 Assistant librarians and 11 library assistants.KLU have one university librarian, 5 Assistant librarians and 16 library Assistants. VU library have one university librarian, 3 Assistant librarian and 5 library Assistants. All 3 university libraries don't have Deputy librarian's .

Table 8. Space Available in University libraries

\begin{tabular}{|l|l|l|l|}
\hline Area of library & GITAM & KLU & VU \\
\hline Area of University Libraries & 50000 sf.t & 1500 sq.m & 1919 Sq.m \\
\hline
\end{tabular}

The table 8 shows The Universities libraries space. The ITAM University library has covered area of 50000 sf.t followed by the KLU 1500 sq.m and VU library has 1919 sq.m.

Table 9. Library Automation

\begin{tabular}{|l|l|l|l|}
\hline Library Automaton & GITAM & KLU & VU \\
\hline Library Software & Libsys & KOHA & EZLIB \\
\hline Internet speed & 1 gbps & $45 \mathrm{mbps}$ & $1 \mathrm{gbps}$ \\
\hline Wifi & $\checkmark$ & $\checkmark$ & $\checkmark$ \\
\hline
\end{tabular}

All Three University libraries are fully automated libraries. GITAM University library using library application software LIBSYS, the KL University library using KOHA open source software and VU using EZLIB Library software, it is developed by University students. The Universities offer WIFI facility their campuses. The internet speed is GITAM 1gbps, KLU 45 MBPS and VU 1GBPS.

\section{Conclusion}

The Deemed Universities have separate individual buildings. The Deemed University libraries are maintained well resources and services for academic and research purpose. The libraries have acquired access to several thousand electronic resources and maintain own databases for their students and faculty members. The present survey the Deemed Universities are maintaining under private sector, survey was aimed to study the conditions of Deemed University libraries in the context of resources, services, library timings, internet facility, staff and library automation activities. The survey highlighted the resources and services of the selected Deemed University libraries in Andhra Pradesh, India and what will be somewhat helpful to the students in communicate realistic education to their present generation for a better tomorrow

\section{Reference}

[1].Seema vasistha, status of libraries in higher technical education institutions: with special reference to deemed universities of North India, Annals of Library and Information studies, Vol.54, June 2007, pp.95-102

[2]. Mehar Singh and Ajay Kumar Arora, Library Resources and Services in the selected University Libraries of Haryana, India, DESIDOC Journal of Library \& Information Technology, Vol.35, No.1, January 2015, pp.47-53

[3]. Daulat Jotwani, Library Resources and services in Indian Institute of Technology, Annals of Library and 
Information Studies, Vol.60, September 2013, pp.204-211

[4]. Veena A. Prakashe and Sapana Tayade, Study of E-Resorces of Indian Institute of Mnagement (IIM) Libraries in India, DESIDOC Journal of Library \& Information Technology, Vol.35, No.3, May 2015, pp217-222

[5]. M.Madhusudan and V. Nagabhusanam "Use of Web Based Libaray Services in Selected University Libraries in India: as tudy, International Journal of Library and Information Studies, Vol.2, No.01,Jan-Mar, 2012

[6]. http://www.gitam.edu

[7]. http://www.kluniversity.in

[8]. http://www.vignanuniversity.org 